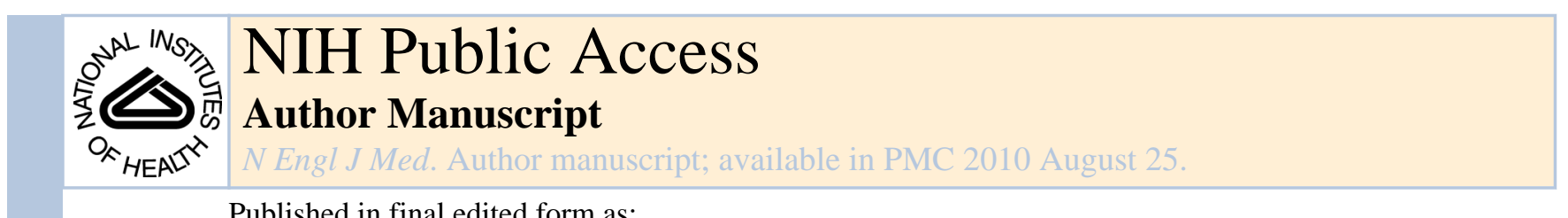

Published in final edited form as:

N Engl J Med. 2010 June 17; 362(24): 2295-2303. doi:10.1056/NEJMra0809890.

\title{
Nicotine Addiction
}

\author{
Neal L. Benowitz, M.D. \\ Division of Clinical Pharmacology and Experimental Therapeutics, Medical Service, San \\ Francisco General Hospital Medical Center; and the Departments of Medicine, Bioengineering \\ and Therapeutic Sciences, University of California, San Francisco - both in San Francisco
}

Cigarette smoking remains a leading cause of preventable disease and premature death in the United States and other countries. On average, 435,000 people in the United States die prematurely from smoking-related diseases each year; overall, smoking causes 1 in 5 deaths. The chance that a lifelong smoker will die prematurely from a complication of smoking is approximately $50 \%{ }^{1}$

Tobacco use is a major cause of death from cancer, cardiovascular disease, and pulmonary disease. Cigarette smoking is also a risk factor for respiratory tract and other infections, osteoporosis, reproductive disorders, adverse postoperative events and delayed wound healing, duodenal and gastric ulcers, and diabetes. In addition, smoking has a strong association with fire-related and trauma-related injuries. Smoking-caused disease is a consequence of exposure to toxins in tobacco smoke. Although nicotine plays a minor role, if any, in causing smoking-induced diseases, addiction to nicotine is the proximate cause of these diseases.

Currently, about 45 million Americans smoke tobacco. Seventy percent of smokers say they would like to quit, and every year, $40 \%$ do quit for at least 1 day. ${ }^{2}$ Some highly addicted smokers make serious attempts to quit but are able to stop only for a few hours. ${ }^{3}$ Moreover, the $80 \%$ who attempt to quit on their own return to smoking within a month, and each year, only $3 \%$ of smokers quit successfully. Unfortunately, the rate at which persons - primarily children and adolescents - become daily smokers nearly matches the quit rate, so the prevalence of cigarette smoking has declined only very slowly in recent years. ${ }^{2}$

This article focuses on nicotine as a determinant of addiction to tobacco and the pharmacologic effects of nicotine that sustain cigarette smoking. Tobacco addiction (like all drug addictions) involves the interplay of pharmacology, learned or conditioned factors, genetics, and social and environmental factors (including tobacco product design and marketing $)^{4}$ (Fig. 1). The pharmacologic reasons for nicotine use are enhancement of mood, either directly or through relief of withdrawal symptoms, and augmentation of mental or physical functions.

\section{BRAIN MECHANISMS NICOTINIC ACETYLCHOLINE RECEPTORS}

Inhalation of smoke from a cigarette distills nicotine from the tobacco in the cigarette. Smoke particles carry the nicotine into the lungs, where it is rapidly absorbed into the pulmonary venous circulation. The nicotine then enters the arterial circulation and moves

Address reprint requests to Dr. Benowitz at the Division of Clinical Pharmacology and Experimental Therapeutics, University of California, San Francisco, Box 1220, San Francisco, CA 94143-1220, or at nbenowitz@ medsfgh.ucsf.edu.

Disclosure forms provided by the author are available with the full text of this article at NEJM.org. 
quickly from the lungs to the brain, where it binds to nicotinic cholinergic receptors (ligandgated ion channels that normally bind acetylcholine). The binding of nicotine at the interface between two subunits of the receptor opens the channel, thereby allowing the entry of sodium or calcium. ${ }^{5}$ The entry of these cations into the cell further activates voltagedependent calcium channels, allowing more calcium to enter. One of the effects of the entry of calcium into a neuron is the release of neurotransmitters.

The nicotinic cholinergic receptor consists of five subunits. ${ }^{6}$ The mammalian brain expresses nine $\alpha$ subunits $\left(\alpha_{2}\right.$ through $\left.\alpha_{10}\right)$ and three $\beta$ subunits $\left(\beta_{2}\right.$ through $\left.\beta_{4}\right)$. The most abundant receptors are $\alpha_{4} \beta_{2}, \alpha_{3} \beta_{4}$, and $\alpha_{7}$, the latter of which are homomeric. The $\alpha_{4} \beta_{2}{ }^{*}$ receptor (the asterisk indicates that other subunits may be present in this receptor) is the principal mediator of nicotine dependence. In mice, disruption of the $\beta_{2}$ subunit gene eliminates the behavioral effects of nicotine; reinserting the gene into the ventral tegmental area restores behavioral responses to nicotine. ${ }^{7,8}$ The $\alpha_{4}$ subunit is an important determinant of sensitivity to nicotine. A mutation affecting a single nucleotide in the pore-forming region of the mouse receptor gene makes it hypersensitive to the effects of nicotine. ${ }^{9}$ Other subunits can form functional receptors. The presence of an $\alpha_{5}$ subunit combined with $\alpha_{4} \beta_{2}$ increases calcium conductance seven times; $\alpha_{5}$ gene variants also alter nicotine responsiveness in cultured human cells. ${ }^{10,11}$ The $\alpha_{3} \beta_{4}$ subtype probably mediates the cardiovascular effects of nicotine. ${ }^{12}$ The $\alpha_{7}$ homomeric receptors are involved in rapid synaptic transmission and long-term potentiation to dopaminergic neurons at excitatory inputs and have a role in learning and sensory gating. ${ }^{13-16}$

\section{NICOTINE AND NEUROTRANSMITTER RELEASE}

Stimulation of nicotinic cholinergic receptors releases a variety of neurotransmitters in the brain. ${ }^{5,17}$ One of them, dopamine, signals a pleasurable experience and is critical for the reinforcing effects (effects that promote self-administration) of nicotine and other drugs of abuse, as well as for compelling drives such as eating. ${ }^{18}$ Experimentally induced lesions in dopamine-releasing neurons prevent self-administration of nicotine in rats. Nicotine releases dopamine in the mesolimbic area, the corpus striatum, and the frontal cortex (Fig. 2). The dopaminergic neurons in the ventral tegmental area of the midbrain and in the shell of the nucleus accumbens are critical in drug-induced reward (both regions have a role in perceptions of pleasure and reward). ${ }^{6}, 18$

Nicotine also augments both glutamate release, which facilitates the release of dopamine, and $\gamma$-aminobutyric acid (GABA) release, which inhibits dopamine release. ${ }^{15,16}$ With longterm exposure to nicotine, some nicotinic cholinergic receptors become desensitized but some do not. As a result, GABA-mediated inhibitory tone diminishes while glutamatemediated excitation persists, thereby increasing excitation of dopaminergic neurons and enhancing responsiveness to nicotine.

A measure of the function of the reward system in rats is the threshold for electrical selfstimulation in the medial forebrain: a lower threshold indicates increased responsiveness to rewarding stimuli. Nicotine lowers the threshold for reward, an effect that can last for more than 30 days. ${ }^{19}$ It also increases activity in the prefrontal cortex, thalamus, and visual system, reflecting activation of corticobasal ganglia-thalamic brain circuits (part of the reward network), and releases dopamine in the striatum. ${ }^{20}$ Other neurotransmitters that may be involved in nicotine addiction are the hypocretins, neuropeptides produced in the lateral hypothalamus that regulate the stimulatory effects of nicotine on reward centers in the brain and modulate self-administration of nicotine in rodents. ${ }^{21}$ 


\section{MONAMINE OXIDASE}

Constituents of cigarette smoke other than nicotine contribute to nicotine addiction. Monoamine oxidases, enzymes located in catecholaminergic and other neurons, catalyze the metabolism of dopamine, norepinephrine, and serotonin. Condensation products of acetaldehyde in cigarette smoke with biogenic amines inhibit the activity of monoamine oxidase type $\mathrm{A}$ and monoamine oxidase type $\mathrm{B}$, and there is evidence that inhibition of monoamine oxidase contributes to the addictiveness of smoking by reducing the metabolism of dopamine. ${ }^{22,23}$

\section{NEUROADAPTATION}

With repeated exposure to nicotine, neuroadaptation (tolerance) to some of the effects of nicotine develops. ${ }^{24}$ As neuroadaptation develops, the number of binding sites on the nicotinic cholinergic receptors in the brain increases, probably in response to nicotinemediated desensitization of receptors. ${ }^{25}$ Desensitization - ligand-induced closure and unresponsiveness of the receptor - is believed to play a role in tolerance and dependence: the symptoms of craving and withdrawal begin in smokers when desensitized $\alpha_{4} \beta_{2}{ }^{*}$ nicotinic cholinergic receptors become responsive during periods of abstinence, such as nighttime sleep. ${ }^{26}$ Nicotine binding of these receptors during smoking alleviates craving and withdrawal.

Cigarette smoking in amounts that are typical for daily smokers maintains near-complete saturation — and thus desensitization — of the $\alpha_{4} \beta_{2}{ }^{*}$ nicotinic cholinergic receptors. ${ }^{27}$ Thus, smokers are probably attempting to avoid withdrawal symptoms when maintaining a desensitized state. By sustaining sufficient levels of plasma nicotine to prevent withdrawal symptoms, they also derive rewarding effects from the conditioned reinforcements associated with smoking, such as the taste and feel of smoke. ${ }^{28}$

Nicotine withdrawal causes anxiety and stress, both of which are powerful incentives to take up smoking again. ${ }^{29}$ The negative affect that typifies the response to nicotine withdrawal probably results in part from a cascade of events involving increased levels of extrahypothalamic corticotropin-releasing factor (CRF) and increased binding of CRF to corticotropin-releasing factor 1 (CRF1) receptors in the brain, thereby activating the CRFCRF1 receptor system, which mediates responses to stress. In rats, anxiety-like behavior and the release of CRF in the central nucleus of the amygdala occur during nicotine withdrawal. ${ }^{30} \mathrm{CRF}$ causes anxiety, whereas the pharmacologic blockade of CRF1 receptors inhibits the anxiogenic effects of nicotine withdrawal. The blockade of CRF1 receptors also prevents the increase in self-administration of nicotine that occurs during abstinence from forced nicotine administration in rats. Thus, both underactivity of the dopaminergic system and activation of the CRF-CRF1 receptor system contribute to the symptoms of nicotine withdrawal that often precipitate relapse.

\section{CLINICAL ASPECTS OF NICOTINE ADDICTION PSYCHOACTIVE EFFECTS OF NICOTINE}

Nicotine induces pleasure and reduces stress and anxiety. Smokers use it to modulate levels of arousal and to control mood. Smoking improves concentration, reaction time, and performance of certain tasks. Relief from withdrawal symptoms is probably the primary reason for this enhanced performance and heightened mood. ${ }^{31}$ Cessation of smoking causes the emergence of withdrawal symptoms: irritability, depressed mood, restlessness, and anxiety. ${ }^{32}$ The intensity of these mood disturbances is similar to that found in psychiatric outpatients. ${ }^{33}$ Anhedonia - the feeling that there is little pleasure in life - can also occur with withdrawal from nicotine, and from other drugs of abuse. ${ }^{34}$ 
The basis of nicotine addiction is a combination of positive reinforcements, including enhancement of mood and avoidance of withdrawal symptoms (Fig. 3) ${ }^{35}$ In addition, conditioning has an important role in the development of tobacco addiction.

\section{CONDITIONED BEHAVIOR}

When a person who is addicted to nicotine stops smoking, the urge to resume is recurrent and persists long after withdrawal symptoms dissipate. With regular smoking, the smoker comes to associate specific moods, situations, or environmental factors - smoking-related cues - with the rewarding effects of nicotine. Typically, these cues trigger relapse.

The association between such cues and the anticipated effects of nicotine, and the resulting urge to use nicotine, constitute a form of conditioning. Studies in animals show that nicotine exposure causes changes in the protein expression of brain cells and in their synaptic connections — a process termed neural plasticity — which underlie conditioning. ${ }^{36,37}$ Nicotine also enhances behavioral responses to conditioned stimuli, which may contribute to compulsive smoking. ${ }^{38}$ Furthermore, studies in nicotine-dependent rats show that conditioned stimuli associated with nicotine withdrawal increase the magnitude of withdrawal through an elevation of the brain's reward threshold. ${ }^{39}$ Thus, cues associated with nicotine withdrawal can decrease the function of the brain's reward systems.

The desire to smoke is maintained, in part, by such conditioning. Smokers usually take a cigarette after a meal, with a cup of coffee or an alcoholic drink, or with friends who smoke. When repeated many times, such situations become a powerful cue for the urge to smoke. Aspects of smoking itself - the manipulation of smoking materials, or the taste, smell, or feel of smoke in the throat - also become associated with the pleasurable effects of smoking. ${ }^{40,41}$ Even unpleasant moods can become conditioned cues for smoking: a smoker may learn that not having a cigarette provokes irritability and that smoking one provides relief. After repeated experiences like this, a smoker can sense irritability from any source as a cue for smoking. Functional imaging studies have shown that exposure to drug-associated cues activates cortical regions of the brain, including the insula (a structure in the cortex associated with certain basic emotions). Smokers who sustain damage to the insula (e.g., brain trauma) are more likely to quit smoking soon after the injury, and to remain abstinent, and are less likely to have conscious urges to smoke than smokers with brain injury that does not affect the insula. ${ }^{42}$

\section{THE TOBACCO ADDICTION CYCLE}

Smoking is a highly efficient form of drug administration. Inhaled nicotine enters the circulation rapidly through the lungs and moves into the brain within seconds. Rapid rates of absorption and entry into the brain cause a strongly felt "rush" and reinforce the effects of the drug. In animals, rapid administration of nicotine potentiates locomotor sensitization, which is linked to reward, and neuroplastic changes in the brain. ${ }^{43}$ The smoking process also provides rapid reinforcement and allows for precise dosing, making it possible for a smoker to obtain desired effects without toxicity. Unlike cigarettes, nicotine medications marketed to promote smoking cessation deliver nicotine slowly, and the risk of abuse is low. ${ }^{44} \mathrm{In}$ addition to delivering nicotine to the brain quickly, cigarettes have been designed with additives and engineering features to enhance its addictiveness. ${ }^{45}$

There is considerable peak-to-trough oscillation in blood levels of nicotine from cigarette to cigarette. Nevertheless, it accumulates in the body over the course of 6 to 9 hours of regular smoking and results in 24 hours of exposure. Arteriovenous differences in nicotine concentrations during cigarette smoking are substantial, with arterial levels up to 10 times as high as venous levels. ${ }^{46}$ The persistence of nicotine in the brain throughout the day and 
night changes the structure and function of nicotinic receptors, stimulating intracellular processes of neuroadaptation.

The pharmacologic basis of nicotine addiction is thus a combination of positive reinforcements, such as enhancement of mood and mental or physical functioning, and avoidance of withdrawal symptoms when nicotine is not available. Figure 4 shows a typical daily smoking cycle. ${ }^{47}$

Smokers tend to take in the same amount of nicotine from day to day to achieve the desired effects. They adjust their smoking behavior to compensate for changes in the availability of nicotine (e.g., when switching from regular to low-yield cigarettes) to regulate the body's level of nicotine ${ }^{48}$ Light smokers (those who smoke $\leq 5$ cigarettes per day) and occasional smokers smoke primarily for the positive reinforcing effects of nicotine and have minimal or no withdrawal symptoms. ${ }^{49}$ They smoke primarily in association with particular activities (after eating a meal or while drinking alcohol), and are less likely to smoke in response to negative affect. Although withdrawal symptoms may not be prominent, many light and occasional smokers have difficulty quitting. Some of them have a high level of dependence, but with pharmacodynamics that differ from those in heavier smokers.

\section{GENETICS OF NICOTINE ADDICTION}

Studies in twins have shown a high degree of heritability of cigarette smoking $(\geq 50 \%)$, including the level of dependence and the number of cigarettes smoked daily. ${ }^{50}$ These studies have also revealed the heritability of the particular symptoms that occur when a smoker stops smoking. ${ }^{51}$

Numerous attempts have been made to identify genes underlying nicotine addiction. ${ }^{50}$ Such studies are problematic because multiple genes and environmental factors determine complex behavior, and the many different dependence phenotypes may have different genetic underpinnings. Candidate genes coding for nicotine-receptor subtypes, dopamine receptors and dopamine transporters, GABA receptors, opiate and cannabinoid receptors, and other types of receptors have been associated with different aspects of smoking behavior. ${ }^{52}$ Subsequent research, however, has not replicated many of the initial findings.

Recent genomewide association studies point to several promising genetic determinants of nicotine dependence. Bierut et al. compared the genomes of smokers who became dependent on nicotine with the genomes of smokers who did not. ${ }^{53}$ Signals from genomewide association studies guided a second-phase candidate-gene association study by Saccone et al. in which several strong genetic associations were uncovered ${ }^{54}$ Most prominent were genes within the $\alpha_{5} / \alpha_{3} / \beta_{4}$ nicotinic cholinergic receptor gene complex on chromosome 15 . This and other genomewide association studies of tobacco addiction have also identified genes affecting cell adhesion and extracellular matrix molecules, which are common among various addictions. These findings are consistent with the idea that neural plasticity and learning are key determinants of individual differences in vulnerability to nicotine dependence and other drug addictions. ${ }^{55}$

Variants associated with nicotine dependence in the $\alpha_{5} / \alpha_{3} / \beta_{4}$ gene region (chromosome 15, $15 \mathrm{q} 25)$ also have a significant association with the number of cigarettes smoked per day, plasma levels of cotinine (a biomarker of nicotine intake), urine levels of tobacco-smoke carcinogens, and the risks of smoking-related diseases. ${ }^{11,56-62}$ The mechanisms of the associations between these variants and disease are probably related to the level of dependence and therefore the level of intake of tobacco-smoke toxins; however, nicotinic cholinergic receptors also modulate inflammatory responses, angiogenesis, and apoptosis, 
and thus account for additional mechanisms through which nicotine could affect the risk of disease. ${ }^{63}$

\section{VULNERABILITY TO ADDICTION}

Tobacco use typically begins in childhood or adolescence $-80 \%$ of smokers begin smoking by 18 years of age. ${ }^{64}$ Although two thirds of young people try cigarette smoking, only 20 to $25 \%$ of them become dependent daily smokers, usually as adults. ${ }^{65,66}$ Risk factors for smoking in childhood or adolescence include peer and parental influences, behavioral problems (e.g., poor school performance), personality characteristics (rebelliousness, risk taking, depression, and anxiety), and genetic influences. ${ }^{64}$

The risk of dependence increases when smoking begins early. ${ }^{64}$ Studies of the developing brain in animals suggest that nicotine can induce permanent changes that lead to addiction. Brain changes in adolescent rats exposed to nicotine are greater than those in exposed adult rats. Adolescent rats that have been exposed to nicotine have higher rates of nicotine selfadministration as adults, which is consistent with the idea that early exposure to nicotine increases the severity of dependence. ${ }^{67,68}$

Tobacco addiction is highly prevalent among persons with mental illness or substance-abuse disorders. ${ }^{69,70}$ The mechanisms of this association are likely to include a shared genetic predisposition, the capacity of nicotine to alleviate some psychiatric symptoms, and the inhibitory effects of tobacco smoke on monoamine oxidase. ${ }^{23,71,72}$

Smoking behavior in women is more strongly influenced by conditioned cues and negative affect; men are more likely to smoke in response to pharmacologic cues, regulating their intake of nicotine more precisely than women. ${ }^{73}$ On average, women metabolize nicotine more quickly than men, ${ }^{74}$ which may contribute to their increased susceptibility to nicotine addiction and may help to explain why, among smokers, it is more difficult for women to quit. $^{75}$

Insofar as smokers regulate their intake of nicotine to maintain particular levels throughout the day, those who metabolize nicotine rapidly take in more cigarette smoke per day than those who metabolize nicotine slowly. Nicotine is metabolized to cotinine primarily by the liver enzyme CYP2A6. ${ }^{76}$ Persons with a genetic basis for slow metabolism (those with variant $C Y P 2 A 6$ genes that are associated with reduced enzyme activity) smoke fewer cigarettes daily than persons with faster metabolism. ${ }^{77}$ The observation that the fraction of smokers with genetically slow metabolism in the population of smokers decreases with the increasing age of the cohort of smokers suggests that those with slow metabolism are more likely to quit than those with faster metabolism. Rapid metabolism of nicotine is associated with more severe withdrawal symptoms and a lower probability of success in quitting during nicotine-patch treatment. ${ }^{78,79}$

\section{CONCLUSIONS}

Nicotine sustains tobacco addiction, a major cause of disability and premature death, by acting on nicotinic cholinergic receptors in the brain to trigger the release of dopamine and other neurotransmitters. Release of dopamine, glutamate, and GABA is particularly important in the development of nicotine dependence, and CRF may play a key role in withdrawal. Neuroadaptation and tolerance involve changes in nicotinic receptors and neural plasticity. Nicotine addiction occurs when smokers come to rely on smoking to modulate mood and arousal, relieve withdrawal symptoms, or both. Light or occasional smokers smoke mainly for positive reinforcement in specific situations. Genetic studies indicate that nicotinic receptor subtypes and the genes involved in neuroplasticity and learning play a part 
in the development of dependence. People with psychiatric or substance-abuse disorders, who account for a large proportion of current smokers, have an increased susceptibility to tobacco addiction. Nicotine is metabolized primarily by the enzyme CYP2A6, and variation in the rate of nicotine metabolism contributes to differences in vulnerability to tobacco dependence and the response to smoking-cessation treatment. An increased understanding of the mechanisms of nicotine addiction has led to the development of novel medications (e.g., varenicline) that act on specific nicotinic receptor subtypes. ${ }^{80}$ The development of other drugs that act on nicotinic receptors and other mediators of nicotine addiction is likely to further enhance the effectiveness of smoking-cessation pharmacotherapy.

\section{Acknowledgments}

Supported by grants from the Flight Attendants Medical Research Institute and the National Institute on Drug Abuse (U.S. Public Health Service grants DA02277 and DA20830).

I thank Marc Olmsted for editorial assistance on an earlier version of the manuscript.

\section{References}

1. Doll R, Peto R, Boreham J, Sutherland I. Mortality in relation to smoking: 50 years' observations on male British doctors. BMJ 2004;328:1519. [PubMed: 15213107]

2. Cigarette smoking among adults and trends in smoking cessation — United States, 2008. MMWR Morb Mortal Wkly Rep 2009;58:1227-32. [PubMed: 19910909]

3. Shiffman S, Scharf DM, Shadel WG, et al. Analyzing milestones in smoking cessation: illustration in a nicotine patch trial in adult smokers. J Consult Clin Psychol 2006;74:276-85. [PubMed: 16649872]

4. Carpenter CM, Wayne GF, Connolly GN. The role of sensory perception in the development and targeting of tobacco products. Addiction 2007;102:136-47. [PubMed: 17207131]

5. Dajas-Bailador F, Wonnacott S. Nicotinic acetylcholine receptors and the regulation of neuronal signalling. Trends Pharmacol Sci 2004;25:317-24. [PubMed: 15165747]

6. Dani JA, De Biasi M. Cellular mechanisms of nicotine addiction. Pharmacol Biochem Behav 2001;70:439-46. [PubMed: 11796143]

7. Maskos U, Molles BE, Pons S, et al. Nicotine reinforcement and cognition restored by targeted expression of nicotinic receptors. Nature 2005;436:103-7. [PubMed: 16001069]

8. Mineur YS, Picciotto MR. Genetics of nicotinic acetylcholine receptors: relevance to nicotine addiction. Biochem Pharmacol 2008;75:323-33. [PubMed: 17632086]

9. Tapper AR, McKinney SL, Nashmi R, et al. Nicotine activation of alpha4 ${ }^{*}$ receptors: sufficient for reward, tolerance, and sensitization. Science 2004;306:1029-32. [PubMed: 15528443]

10. Tapia L, Kuryatov A, Lindstrom J. Ca2+ permeability of the (alpha4)3(beta2)2 stoichiometry greatly exceeds that of (alpha4)2(beta2)3 human acetylcholine receptors. Mol Pharmacol 2007;71:769-76. [PubMed: 17132685]

11. Bierut LJ, Stitzel JA, Wang JC, et al. Variants in nicotinic receptors and risk for nicotine dependence. Am J Psychiatry 2008;165:1163-71. [PubMed: 18519524]

12. Aberger K, Chitravanshi VC, Sapru HN. Cardiovascular responses to microinjections of nicotine into the caudal ventrolateral medulla of the rat. Brain Res 2001;892:138-46. [PubMed: 11172759]

13. Levin ED, Bettegowda C, Blosser J, Gordon J. AR-R17779, and alpha7 nicotinic agonist, improves learning and memory in rats. Behav Pharmacol 1999;10:675-80. [PubMed: 10780509]

14. Hajós M, Hurst RS, Hoffmann WE, et al. The selective alpha7 nicotinic acetylcholine receptor agonist PNU-282987 [N-[(3R)-1-Azabicyclo[2.2.2]oct-3-yl]-4-chlorobenzamide hydrochloride] enhances GABAergic synaptic activity in brain slices and restores auditory gating deficits in anesthetized rats. J Pharmacol Exp Ther 2005;312:1213-22. [PubMed: 15523001]

15. Mansvelder HD, McGehee DS. Long-term potentiation of excitatory inputs to brain reward areas by nicotine. Neuron 2000;27:349-57. [PubMed: 10985354] 
16. Cellular and synaptic mechanisms of nicotine addiction. J Neurobiol 2002;53:606-17. Idem. [PubMed: 12436424]

17. Wonnacott S. Presynaptic nicotinic ACh receptors. Trends Neurosci 1997;20:92-8. [PubMed: 9023878]

18. Nestler EJ. Is there a common molecular pathway for addiction? Nat Neurosci 2005;8:1445-9. [PubMed: 16251986]

19. Kenny PJ, Markou A. Nicotine self-administration acutely activates brain reward systems and induces a long-lasting increase in reward sensitivity. Neuropsychopharmacology 2006;31:120311. [PubMed: 16192981]

20. Brody AL. Functional brain imaging of tobacco use and dependence. J Psychiatr Res 2006;40:40418. [PubMed: 15979645]

21. Hollander JA, Lu Q, Cameron MD, Kamenecka TM, Kenny PJ. Insular hypocretin transmission regulates nicotine reward. Proc Natl Acad Sci U S A 2008;105:19480-5. [PubMed: 19033203]

22. Fowler JS, Logan J, Wang GJ, Volkow ND. Monoamine oxidase and cigarette smoking. Neurotoxicology 2003;24:75-82. [PubMed: 12564384]

23. Lewis A, Miller JH, Lea RA. Monoamine oxidase and tobacco dependence. Neurotoxicology 2007;28:182-95. [PubMed: 16859748]

24. Wang H, Sun X. Desensitized nicotinic receptors in brain. Brain Res Brain Res Rev 2005;48:42037. [PubMed: 15914250]

25. Govind AP, Vezina P, Green WN. Nicotine-induced upregulation of nicotinic receptors: underlying mechanisms and relevance to nicotine addiction. Biochem Pharmacol 2009;78:756-65. [PubMed: 19540212]

26. Dani JA, Harris RA. Nicotine addiction and comorbidity with alcohol abuse and mental illness. Nat Neurosci 2005;8:1465-70. [PubMed: 16251989]

27. Brody AL, Mandelkern MA, London ED, et al. Cigarette smoking saturates brain alpha 4 beta 2 nicotinic acetylcholine receptors. Arch Gen Psychiatry 2006;63:907-15. [PubMed: 16894067]

28. Balfour DJ. The neurobiology of tobacco dependence: a preclinical perspective on the role of the dopamine projections to the nucleus accumbens. Nicotine Tob Res 2004;6:899-912. [Erratum, Nicotine Tob Res 2005;7:307.]. [PubMed: 15801566]

29. Le Moal M, Koob GF. Drug addiction: pathways to the disease and pathophysiological perspectives. Eur Neuropsychopharmacol 2007;17:377-93. [PubMed: 17169534]

30. George O, Ghozland S, Azar MR, et al. CRF-CRF1 system activation mediates withdrawalinduced increases in nicotine self-administration in nicotine-dependent rats. Proc Natl Acad Sci U S A 2007;104:17198-203. [PubMed: 17921249]

31. Knott V, Heenan A, Shah D, Bolton K, Fisher D, Villeneuve C. Electrophysiological evidence of nicotine's distracter-filtering properties in non-smokers. J Psychopharmacol. 2009 November 25; (Epub ahead of print).

32. Hughes JR, Hatsukami D. Signs and symptoms of tobacco withdrawal. Arch Gen Psychiatry 1986;43:289-94. [PubMed: 3954551]

33. Hughes JR. Clinical significance of tobacco withdrawal. Nicotine Tob Res 2006;8:153-6. [PubMed: 16766409]

34. Koob GF, LeMoal M. Drug abuse: hedonic homeostatic dysregulation. Science 1997;278:52-8. [PubMed: 9311926]

35. Dani JA, Heinemann S. Molecular and cellular aspects of nicotine abuse. Neuron 1996;16:905-8. [PubMed: 8630247]

36. Kauer JA, Malenka RC. Synaptic plasticity and addiction. Nat Rev Neurosci 2007;8:844-58. [PubMed: 17948030]

37. Davis JA, Gould TJ. Associative learning, the hippocampus, and nicotine addiction. Curr Drug Abuse Rev 2008;1:9-19. [PubMed: 19630701]

38. Olausson P, Jentsch JD, Taylor JR. Repeated nicotine exposure enhances responding with conditioned reinforcement. Psychopharmacology (Berl) 2004;173:98-104. [PubMed: 14727001]

39. Kenny PJ, Markou A. Conditioned nicotine withdrawal profoundly decreases the activity of brain reward systems. J Neurosci 2005;25:6208-12. [PubMed: 15987950] 
40. Rose JE, Behm FM, Levin ED. Role of nicotine dose and sensory cues in the regulation of smoke intake. Pharmacol Biochem Behav 1993;44:891-900. [PubMed: 8469698]

41. Rose JE, Behm FM, Westman EC, Johnson M. Dissociating nicotine and non-nicotine components of cigarette smoking. Pharmacol Biochem Behav 2000;67:71-81. [PubMed: 11113486]

42. Naqvi NH, Rudrauf D, Damasio H, Bechara A. Damage to the insula disrupts addiction to cigarette smoking. Science 2007;315:531-4. [PubMed: 17255515]

43. Samaha AN, Yau WY, Yang P, Robinson TE. Rapid delivery of nicotine promotes behavioral sensitization and alters its neurobiological impact. Biol Psychiatry 2005;57:351-60. [PubMed: 15705350]

44. Houtsmuller EJ, Henningfield JE, Stitzer ML. Subjective effects of the nicotine lozenge: assessment of abuse liability. Psychopharmacology (Berl) 2003;167:20-7. [PubMed: 12616334]

45. Henningfield JE, Benowitz NL, Connolly GN, et al. Reducing tobacco addiction through tobacco product regulation. Tob Control 2004;13:132-5. [PubMed: 15175528]

46. Henningfield JE, Stapleton JM, Benowitz NL, Grayson RF, London ED. Higher levels of nicotine in arterial than in venous blood after cigarette smoking. Drug Alcohol Depend 1993;33:23-9. [PubMed: 8370337]

47. Benowitz, NL. Compensatory smoking of low yield cigarettes. In: Shopland, DR.; Burns, DM.; Benowitz, NL.; Amacher, RH., editors. Risks associated with smoking cigarettes with low machine-measured yields of tar and nicotine. Bethesda, MD: National Institutes of Health; 2001. p. 3964(NIH publication no. 02-5074.)

48. Cigarette smoking and nicotine addiction. Med Clin North Am 1992;76:415-37. Idem. [PubMed: 1548969]

49. Shiffman S. Light and intermittent smokers: background and perspective. Nicotine Tob Res 2009;11:122-5. [PubMed: 19246630]

50. Lessov-Schlaggar CN, Pergadia ML, Khroyan TV, Swan GE. Genetics of nicotine dependence and pharmacotherapy. Biochem Pharmacol 2008;75:178-95. [PubMed: 17888884]

51. Xian H, Scherrer JF, Madden PA, et al. Latent class typology of nicotine withdrawal: genetic contributions and association with failed smoking cessation and psychiatric disorders. Psychol Med 2005;35:409-19. [PubMed: 15841876]

52. Ho MK, Tyndale RF. Overview of the pharmacogenomics of cigarette smoking. Pharmacogenomics J 2007;7:81-98. [PubMed: 17224913]

53. Bierut LJ, Madden PA, Breslau N, et al. Novel genes identified in a high-density genome wide association study for nicotine dependence. Hum Mol Genet 2007;16:24-35. [PubMed: 17158188]

54. Saccone SF, Hinrichs AL, Saccone NL, et al. Cholinergic nicotinic receptor genes implicated in a nicotine dependence association study targeting 348 candidate genes with 3713 SNPs. Hum Mol Genet 2007;16:36-49. [PubMed: 17135278]

55. Uhl GR, Liu QR, Drgon T, Johnson C, Walther D, Rose JE. Molecular genetics of nicotine dependence and abstinence: whole genome association using 520,000 SNPs. BMC Genet 2007;8:10. [PubMed: 17407593]

56. Berrettini W, Yuan X, Tozzi F, et al. Alpha-5/alpha-3 nicotinic receptor subunit alleles increase risk for heavy smoking. Mol Psychiatry 2008;13:368-73. [PubMed: 18227835]

57. Thorgeirsson TE, Geller F, Sulem $P$, et al. A variant associated with nicotine dependence, lung cancer and peripheral arterial disease. Nature 2008;452:638-42. [PubMed: 18385739]

58. Amos CI, Wu X, Broderick P, et al. Genome-wide association scan of tag SNPs identifies a susceptibility locus for lung cancer at 15q25.1. Nat Genet 2008;40:616-22. [PubMed: 18385676]

59. Hung RJ, McKay JD, Gaborieau V, et al. A susceptibility locus for lung cancer maps to nicotinic acetylcholine receptor subunit genes on 15q25. Nature 2008;452:633-7. [PubMed: 18385738]

60. Pillai SG, Ge D, Zhu G, et al. A genome-wide association study in chronic obstructive pulmonary disease (COPD): identification of two major susceptibility loci. PLoS Genet 2009;5(3):e1000421. [PubMed: 19300482]

61. Le Marchand L, Derby KS, Murphy SE, et al. Smokers with the CHRNA lung cancer-associated variants are exposed to higher levels of nicotine equivalents and a carcinogenic tobacco-specific nitrosamine. Cancer Res 2008;68:9137-40. [PubMed: 19010884] 
62. Keskitalo K, Broms U, Heliövaara M, et al. Association of serum cotinine level with a cluster of three nicotinic acetylcholine receptor genes (CHRNA3/CHRNA5/CHRNB4) on chromosome 15. Hum Mol Genet 2009;18:4007-12. [PubMed: 19628476]

63. Thunnissen FB. Acetylcholine receptor pathway and lung cancer. J Thorac Oncol 2009;4:943-6. [PubMed: 19633471]

64. Lynch, BS.; Bonnie, RJ. Growing up tobacco free — preventing nicotine addiction in children and youths. Washington, DC: National Academy Press; 1994. The nature of nicotine addiction; $p$. 28-68.

65. Johnston, LD.; O’Malley, PM.; Bachman, JG.; Schulenberg, JE. Monitoring the future: national survey results on drug use, 1975-2006. Bethesda, MD: National Institute on Drug Abuse; 2007. (NIH publication no. 07-6205.)

66. Kandel D, Schaffran C, Griesler P, Samuolis J, Davies M, Galanti R. On the measurement of nicotine dependence in adolescence: comparisons of the mFTQ and a DSM-IV-based scale. J Pediatr Psychol 2005;30:319-32. [PubMed: 15863429]

67. Placzek AN, Zhang TA, Dani JA. Age dependent nicotinic influences over dopamine neuron synaptic plasticity. Biochem Pharmacol 2009;78:686-92. [PubMed: 19464268]

68. Dwyer JB, McQuown SC, Leslie FM. The dynamic effects of nicotine on the developing brain. Pharmacol Ther 2009;122:125-39. [PubMed: 19268688]

69. Lasser K, Boyd JW, Woolhandler S, Himmelstein DU, McCormick D, Bor DH. Smoking and mental illness: a population-based prevalence study. JAMA 2000;284:2606-10. [PubMed: 11086367]

70. Kalman D, Morissette SB, George TP. Co-morbidity of smoking in patients with psychiatric and substance use disorders. Am J Addict 2005;14:106-23. [PubMed: 16019961]

71. Ziedonis D, Hitsman B, Beckham JC, et al. Tobacco use and cessation in psychiatric disorders: National Institute of Mental Health report. Nicotine Tob Res 2008;10:1691-715. [PubMed: 19023823]

72. Martin LF, Freedman R. Schizophrenia and the alpha7 nicotinic acetylcholine receptor. Int Rev Neurobiol 2007;78:225-46. [PubMed: 17349863]

73. Perkins KA, Jacobs L, Sanders M, Caggiula AR. Sex differences in the subjective and reinforcing effects of cigarette nicotine dose. Psychopharmacology (Berl) 2002;163:194-201. [PubMed: 12202966]

74. Benowitz NL, Lessov-Schlaggar CN, Swan GE, Jacob P III. Female sex and oral contraceptive use accelerate nicotine metabolism. Clin Pharmacol Ther 2006;79:480-8. [PubMed: 16678549]

75. Perkins KA, Scott J. Sex differences in long-term smoking cessation rates due to nicotine patch. Nicotine Tob Res 2008;10:1245-50. [PubMed: 18629735]

76. Hukkanen J, Jacob P III, Benowitz NL. Metabolism and disposition kinetics of nicotine. Pharmacol Rev 2005;57:79-115. [PubMed: 15734728]

77. Malaiyandi V, Sellers EM, Tyndale RF. Implications of CYP2A6 genetic variation for smoking behaviors and nicotine dependence. Clin Pharmacol Ther 2005;77:145-58. [PubMed: 15735609]

78. Lerman C, Tyndale R, Patterson F, et al. Nicotine metabolite ratio predicts efficacy of transdermal nicotine for smoking cessation. Clin Pharmacol Ther 2006;79:600-8. [PubMed: 16765148]

79. Rubinstein ML, Benowitz NL, Auerback GM, Moscicki AB. Rate of nicotine metabolism and withdrawal symptoms in adolescent light smokers. Pediatrics 2008;122(3):e643-e647. [PubMed: 18762498]

80. Rollema H, Chambers LK, Coe JW, et al. Pharmacological profile of the alpha-4beta2 nicotinic acetylcholine receptor partial agonist varenicline, an effective smoking cessation aid. Neuropharmacology 2007;52:985-94. [PubMed: 17157884] 


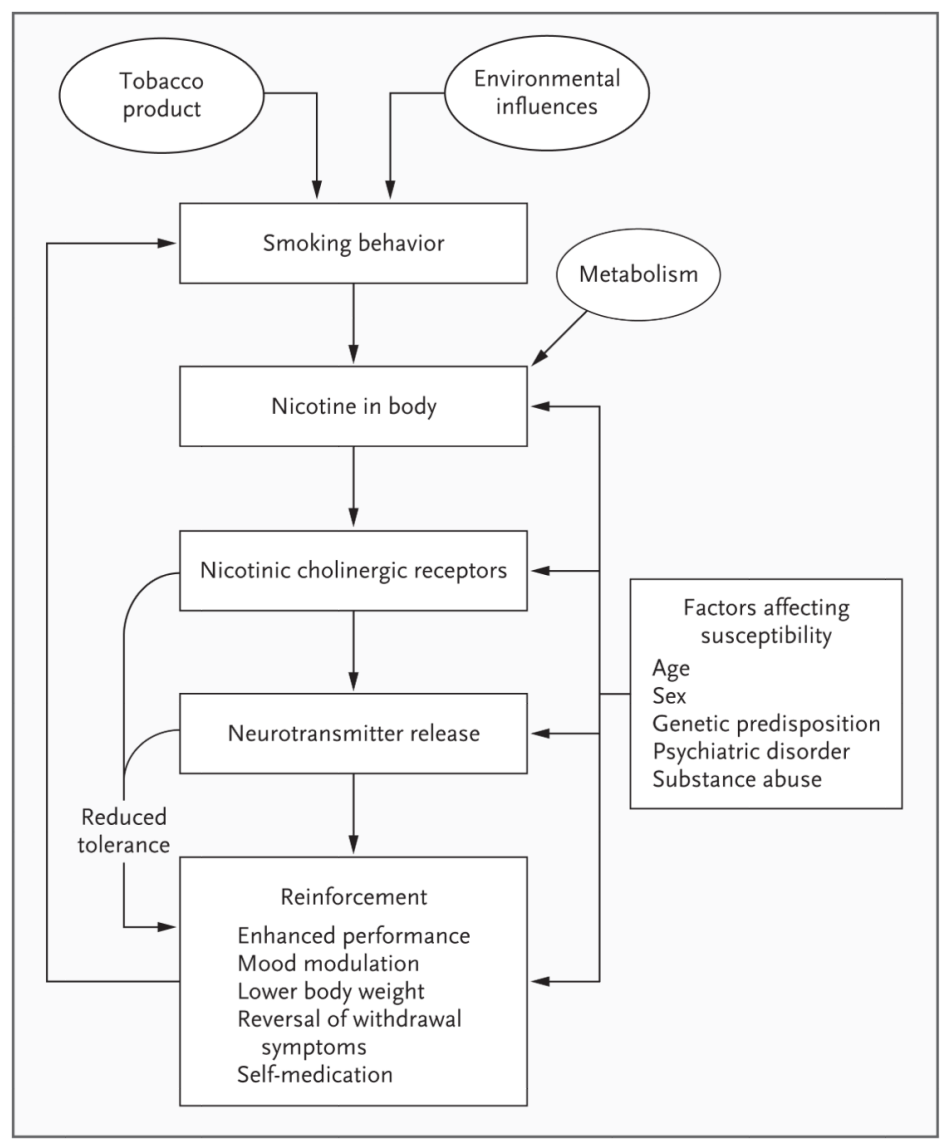

Figure 1. The Biology of Nicotine Addiction

Nicotine acts on nicotinic cholinergic receptors, triggering the release of neurotransmitters that produce psychoactive effects that are rewarding. With repeated exposure, tolerance develops to many of the effects of nicotine, thereby reducing its primary reinforcing effects and inducing physical dependence (i.e., withdrawal symptoms in the absence of nicotine). Smoking behavior is influenced by pharmacologic feedback and by environmental factors such as smoking cues, friends who smoke, stress, and product advertising. Levels of nicotine in the body in relation to a particular level of nicotine intake from smoking are modulated by the rate of nicotine metabolism, which occurs in the liver largely by means of the enzyme CYP2A6. Other factors that influence smoking behavior include age, sex, genetics, mental illness, and substance abuse. 


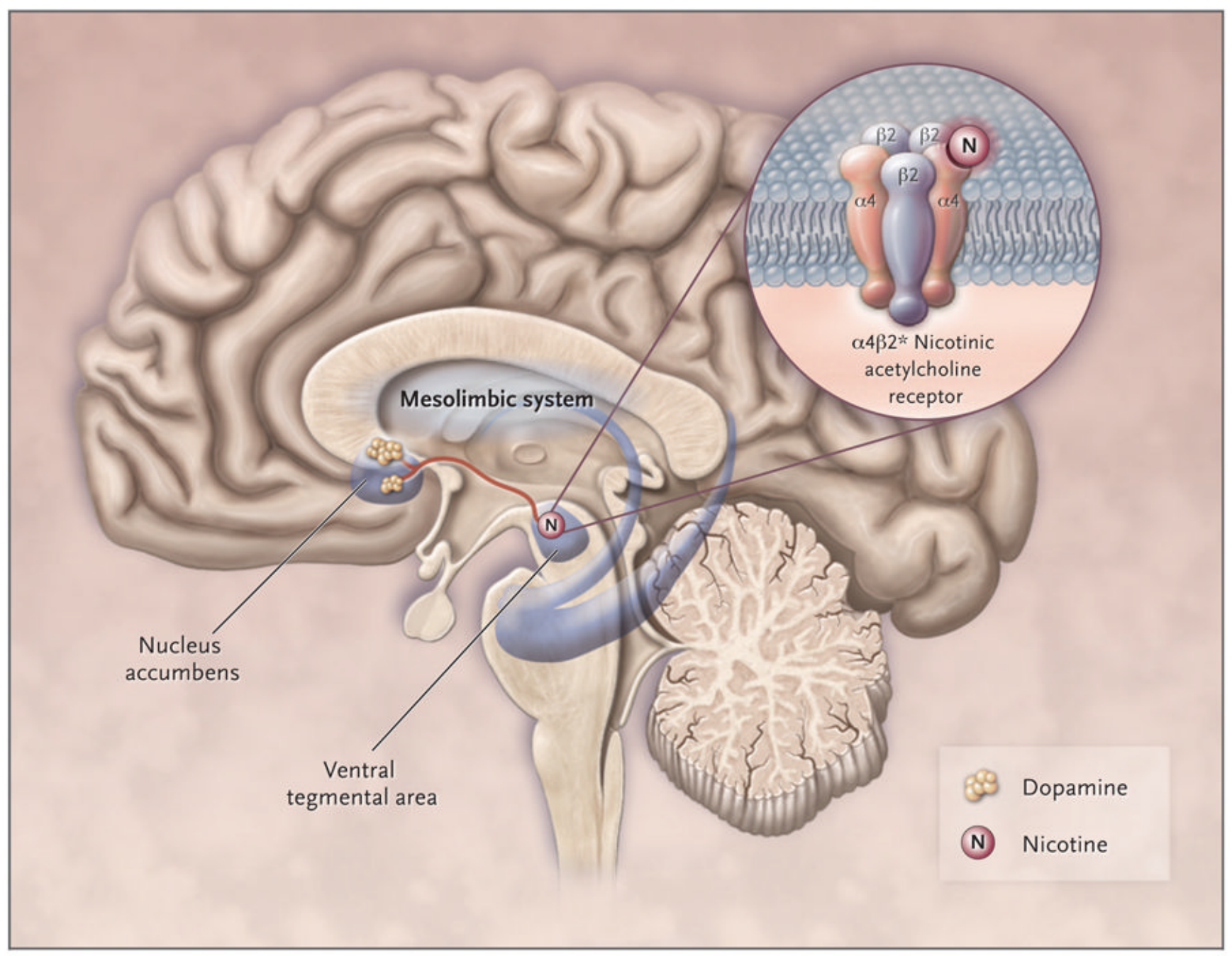

Figure 2. Role of the Mesolimbic Dopamine System in Nicotine Activity

Nicotine activates $\alpha_{4} \beta_{2}{ }^{*}$ receptors in the ventral tegmental area, resulting in dopamine release in the shell of the nucleus accumbens. 


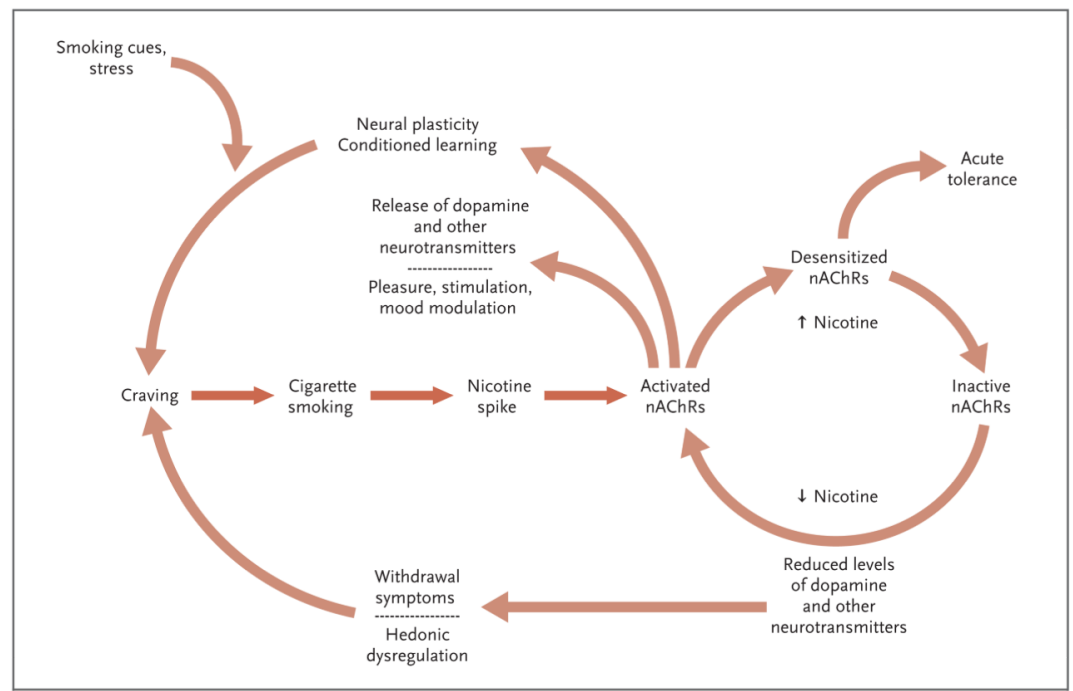

Figure 3. Molecular and Behavioral Aspects of Nicotine Addiction

Craving - induced by smoking cues, stressors, or a desire to relieve withdrawal symptoms - triggers the act of smoking a cigarette, which delivers a spike of nicotine to the brain. Nicotinic cholinergic receptors (nAChRs) are activated, resulting in the release of dopamine and other neurotransmitters, which in turn cause pleasure, stimulation, and mood modulation. Receptor activation also results in the development of new neural circuits (neural plasticity) and, in association with environmental cues, behavioral conditioning. After being activated by nicotine, nAChRs ultimately become desensitized to it, which results in short-term tolerance of nicotine and reduced satisfaction from smoking. In the time between smoking cigarettes, or after quitting tobacco use, brain nicotine levels decline, which leads to reduced levels of dopamine and other neurotransmitters and to withdrawal symptoms, including craving. In the absence of nicotine, nAChRs regain their sensitivity to nicotine and become reactivated in response to a new dose. Adapted from Dani and Heinemann. ${ }^{35}$ 


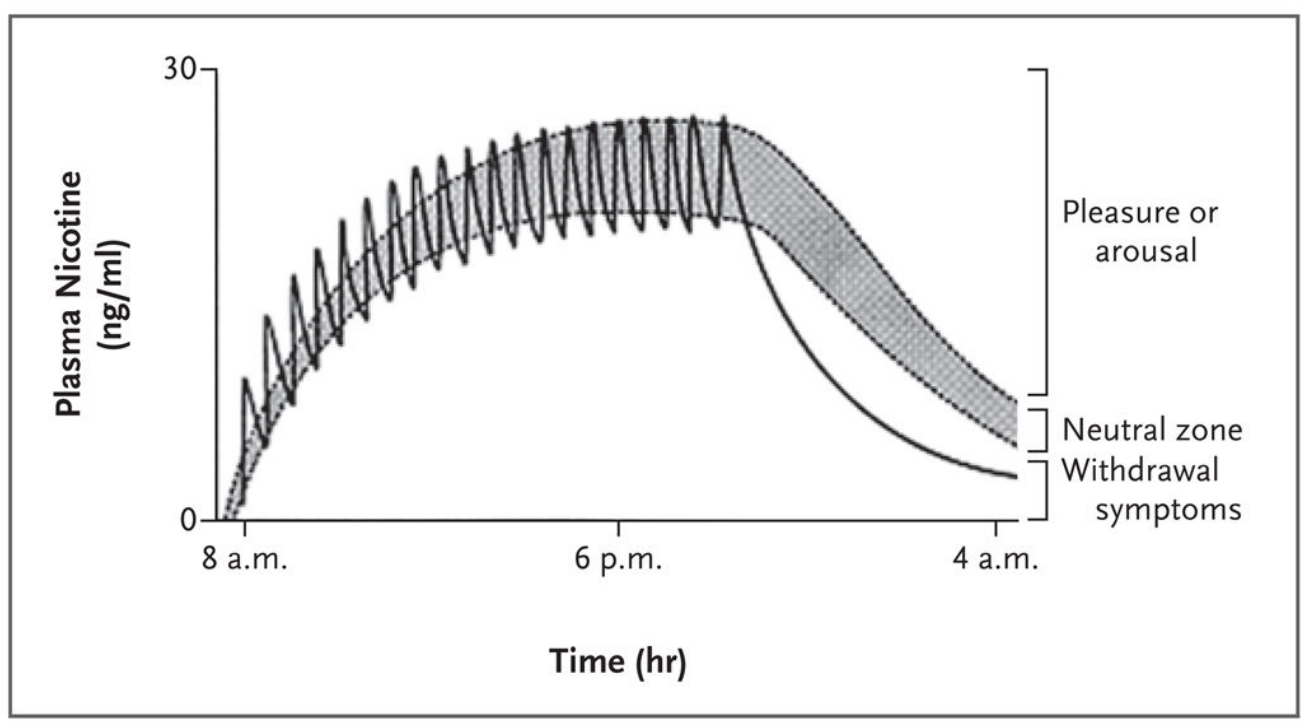

Figure 4. The Tobacco Addiction Cycle

The first cigarette of the day has a substantial pharmacologic effect, primarily arousal, but at the same time, tolerance to nicotine begins to develop. A second cigarette is smoked later, at a time when the smoker has learned that there is some regression of tolerance. With subsequent smoking, there is an accumulation of nicotine in the body, resulting in a greater level of tolerance, and withdrawal symptoms become more pronounced between successive cigarettes. The shaded area of the graph represents the affective neutral zone that exists between the threshold level of nicotine needed to produce pleasure and arousal and the threshold level below which withdrawal symptoms will occur. Transiently high levels of nicotine in the brain after individual cigarettes are smoked may partially overcome tolerance, but the primary (euphoric) effects of nicotine tend to lessen throughout the day. Abstinence overnight allows considerable resensitization to the actions of nicotine. Adapted from Benowitz. ${ }^{47}$ 